\title{
Comparative Study on Bacterial Load in Intestine, Gills and Skin of Cultured African Catfish (Clarias gariepinus) from Different Locations in Rivers State, Nigeria
}

\author{
Abu Onisokyetu Monica Godwin \& Uwadirioha Uchechi \\ Department of Fisheries and Aquaculture, Faculty of Agriculture, University of Port Harcourt, Choba, \\ Port Harcourt, Rivers State, Nigeria.
}

\begin{abstract}
Comparative study on bacterial load in intestine, gills and skin of cultured African catfish (Clarias gariepinus) from different locations (Agip; Aluu and Woji) all in Rivers State were evaluated. The result obtained indicated that the specie Streptococcus accounts for the highest bacterial occurrence (42.9\%) and Pseudomonas spp. and E.coli. had the lowest (7.14\%). In all the three locations under consideration the highest bacteria $\left(0.0129 \pm 0.0040 \times 10^{5} \mathrm{CFU} / \mathrm{g}\right)$ was found in the intestine of the fish sampled from Aluu environment, while the lowest $\left(0.0046 \pm 0.0019 \times 10^{5} \mathrm{CFU} / \mathrm{g}\right)$ was recorded in the skin of fish sampled from Agip estate. The results of this study revealed a higher degree of bacteriological contamination in different organs of $C$. gariepinus fish in all the locations. The presence of these pathogenic organisms in these samples of fish could pose a serious threat and hazard to the consumers. Hence, C. gariepinus fish should be processed properly before consumption.
\end{abstract}

Keywords: Micro-biology, Catfish, Aquaculture, Environment, Rivers State

\section{INTRODUCTION}

Fish and seafood constitute an important food component for a large section of world population (Wafaa et al., 2011). The Food and Agricultural Organization (FAO) (1994) cited by Emikpe et al. (2011) asserted that fish contributes about $60 \%$ of the world supply of protein and that $60 \%$ of the developing countries derives more than $30 \%$ of their animal protein from fish. The annual domestic fish production in Nigeria is estimated at 600,000 metric tons per annum while the annual consumption is estimated at 2.66 million metric tons per annum. The deficit or gap is taking care of by importation of fish from outside the country spending $\$ 100$ Billion annually in fish importation (FDF, 2010). Currently the country spends an estimate of 125 billion on 1.9 million tonnes of fish per annum. The total demand for fish in the country is 2.7 million tonnes ad which 800,000 tonnes are currently produced locally. The deficit of 1.9 million tonnes is met by imports (FDF, 2014). The need to increase our domestic production and an attempt to reduce the amount of money spent on fish importation can therefore not be over emphasized. Many Nigerians have recognized that Nigeria has market for fish and dived into fish production through aquaculture.

In trying to do this, the African Catfish (Clarias gariepinus) is a choice culture fish because it a hardy fish, a delicacy of consumers, and commands good price. The African catfish (C. gariepinus) has been reported to be a very important freshwater fish in Nigeria and also the aquaculture industry in Nigeria mainly involves African catfish production (FDF, 2007). It has enjoyed wide acceptability in most parts of are implicated.

Fish acts as an important food vehicle for some zoonotic pathogens such as Salmonella and vibrios and the contamination of fish with pathogens is a major public health concern. However, consumption of fin fish and shell fish may also cause disease due to infection or intoxication. Some of these diseases have been specifically associated with pathogen which are resistant to antibiotics (Adebayo Tayo et al., 2012a; Edun et al., 2015) and this poses a great risk to human health. Although only a few infectious agents in fish are able to infect humans some exceptions exist that may result in fatalities.

Fish and shell fish not only transmit disease to man but are themselves subject to many diseases and are capable of transmitting many of the established food borne microbial infections and intoxications. 
Fish take a larger number of bacteria into their gut from water sediment and food (Adeleye et al., 2010). It has been well known that both fresh and brackish water fishes can harbor human pathogenic bacteria, particularly the coliform group. Faecal coliform in fish demonstrates the level of pollution in their environment because coliform are not named flora of bacteria in fish (Adebayo-Tayo et al., 2012b).

The consumption of fresh African catfish (C. gariepinus) is on the increase in both rural and urban centers in Nigeria (FDF, 2007; Emikpe et al., 2011). However, there is dearth of information on the microbial load in African catfish (C. gariepinus) sampled from ponds. Thus, this study is designed to provide information on bacteria organisms that are found in the gills, intestine and on the skin of Clarias gariepinus from ponds of different cultured environment in Rivers State.

\section{Materials AND Methods}

\section{Collection of Samples}

Twelve live $C$. gariepinus ranging from $30.0 \mathrm{~cm}$ to $43.2 \mathrm{~cm}$ in length and $290.2 \mathrm{~g}$ to $468 \mathrm{~g}$ in weight were collected from fish ponds of private owned fish farms in Omuike in Aluu, Agip and Woji areas of Rivers state. The fishes were caught using a drag net and were taken immediately to the laboratory for analysis.

\section{Preparation of Media}

Nutrient Agar was used for the isolation of bacteria from the fish samples and it was obtained commercially in powdered form. The media was prepared according to the manufacturers guide; $28.0 \mathrm{~g}$ was dissolved in $1 \mathrm{~L}$ of distilled water and sterilized by autoclaving at $121^{\circ} \mathrm{c}$ for 15 minute. The media was allowed to cool and then poured into sterile disposable petri dishes and allowed to solidify.

\section{Preparation of Samples/ Microbiological Analysis}

The fishes were first killed and their length and weight were measured. The fish skin was which was placed on a clean foil and weighed to get $1 \mathrm{~g}$ of skin; $1 \mathrm{~g}$ of intestine and $10 \mathrm{~g}$ of gills. The fish tissues where then put into $9 \mathrm{ml}$ of distilled water to give 1:10 dilution and shaken thoroughly. $1 \mathrm{ml}$ of the pond water samples was also pippeted into $9 \mathrm{ml}$ of distilled water to also give 1:10 dilution. The stock solution was serially diluted up to $10^{-5}$ as described by Willey et al. (2008). Plating (spread plate method) was done by inoculating $0.1 \mathrm{ml}$ of the dilution on nutrient agar in duplicate plates using $10^{-4}$ and $10^{-5}$ and spreading with a sterile glass spreader, the plates were then incubated for 18-24 hours at ambient temperature. The plates were examined after incubation and the number of colony forming units (CFU) that developed were counted and recorded.

\section{Isolation}

Isolation of the colonies was done by sub-culturing representative colonies on a freshly prepared nutrient agar. This was then incubated at $31^{\circ} \mathrm{C}$ for 24 hours to obtain pure cultures.

\section{Characterization/Identification of Isolates}

The characterization of the organisms was based on colonial, morphological and biochemical characteristics of colonies. Macroscopic examination of surface colonies on nutrient agar medium was used to determine the colour, edge, elevation, surface, shape and arrangement of microorganisms. Morphological characteristics were studied on the oil immersed slide under the microscope after gram staining.

\section{Gram's Stain}

The gram staining technique was used to differentiate the gram positive from gram negative isolates based on the gram staining technique described by Christian Gram in 1884 (Willey et al., 2008). The principle of the test is based on the cell wall properties of the two bacterial classes. A smear of the isolate was made and fixed on a grease free slide and passed over a flame. Firstly crystal violet was poured on the smear which was rinsed off after one minute; lugos iodine (which is the mordant) was then poured on the smear and rinsed off after one minute. Few drops of ethanol was then used to decolorize the smear which was rinsed off after 5 seconds. Lastly, fuchsin (which is the counter stain) was poured on the smear and was rinsed off after one minute. The slide was air dried afterwards, immersion oil was then dropped on the slide (a drop) which was placed under the microscope and viewed using a magnification of $\mathrm{x} 100$. 


\section{Biochemical Test}

The Biochemical tests that were carried out on the bacteria isolates were Catalyst, Coagulase Motility, Oxidaze, Sugar fermentation, Methyl-Red and Voges-Proskauer test.

\section{Catalase Test}

This test detects aerobic bacteria based on the present of enzyme catalase that convert hydrogen peroxide to water and oxygen. It is used to differentiate Streptococcus catalase negative from Staphylococcus catalase positive and Bacillus catalase positive from Clostridium negative (Willey et al., 2008). A loop full of the organism test was smeared on a clean grease-free slide, drop of $3 \%$ hydrogen peroxide was added to it. Presence of effervescence to indicate hibernation of oxygen is a positive test while no effervesence is a negative test.

\section{Coagulase Test}

This test detects the enzyme coagulase that causes plasma to clot. It is an important test used in the differentiation of Staphylococcus aureus from S. epidemidis (Willey et al., 2008). The slide coagulase method, as described by Ogbulie et al., (2001) was used. A drop of plasma was dropped on a slide and a loopfull of the isolate was added to the plasma on the slide and the mixture rocked for 10 seconds to observe for clumps that depicts a positive test.

\section{Motility Test}

This test as described by Cheeseborough, (1985) is said to separate motile from non-motile bacteria based on the knowledge that motile bacteria "swarm" in semi solid agar to give a diffuse spreading growth that is easily detected by the naked eye. $7.25 \mathrm{~g}$ of nutrient agar was dissolved in $500 \mathrm{ml}$ of distilled water. The mixture was boiled and stirred for proper dissolution and $10 \mathrm{ml}$ was dispensed into test tubes and autoclaved at $121^{\circ} \mathrm{C}$ for 15 minutes. The medium was allowed to become semi-solid in the test tubes and overnight culture was stabbed into the medium and incubated at $37^{\circ} \mathrm{C}$ for 24 hours. A positive test is indicated by a swarming movement away that is maybe at the top or bottom from the stab line while a negative test would remain in the stab line.

\section{Oxidase Test}

This test depicts the presence of oxidase enzymes in the isolates that will catalyse the transport of electrons between electron donors in the bacteria and a redox dye (Tetramethy - $p$ phenylenediamine) to reduce the dye to deep purple (Cheeseborough, 1985). The wet filter paper method was used. A strip of filter paper was soaked with oxidase reagent and placed in a petri dish and a speck of culture smeared on it using glass rod. Deep intense purple colour depicts a positive test while no colour change is negative.

\section{Sugar Fermentation Test}

This test shows the ability of microorganisms to ferment certain sugars. Three sugars were used; two disaccharides (lactose and maltose) and one monosaccharide (glucose) (Cowan, 1974). 3g of peptone powder was dissolved in $180 \mathrm{ml}$ of distilled water in appropriately labeled conical flasks. $0.1 \mathrm{~g}$ of phenol red was dissolved in $50 \mathrm{ml}$ of distilled water and $2 \mathrm{ml}$ of the resulting indicator solution dispensed into each conical flask and shaken thoroughly. The solution was dispensed in $5 \mathrm{ml}$ amounts into test tubes with inverted Durham's tubes and autoclaved for 15minutes. The test tubes were then inoculated with loop ful of test organisms and incubated for 24 hours. The test was observed for acid production leading to colour change (red to yellow) as well as gas production that causes the displacement of the liquid in the inverted Durham's tubes which indicates a positive test.

\section{Methyl-Red Test}

This test was employed to check the ability of microorganisms to produce sufficient acid during glucose fermentation and conditions such that the $\mathrm{pH}$ of an old culture is sustained below a value of 4.5 (Cheeseborough, 1985). Buffered glucose broth was prepared by dissolving $5 \mathrm{~g}$ each of peptone and dipotassium hydrogen phosphate $\left(\mathrm{K}_{2} \mathrm{HPO}_{4}\right)$, dispensing $5 \mathrm{ml}$ amount into test and autoclave at $121^{\circ} \mathrm{C}$ for 15 minutes. $10 \%$ glucose was prepared by dissolving $5 \mathrm{~g}$ of glucose in $50 \mathrm{ml}$ of distilled water and sterilized by boiling for 6 minutes. $0.25 \mathrm{ml}$ of the resulting glucose solution was added to each tube and inoculated with the organism. The set up was incubated at $37^{\circ} \mathrm{C}$ for 48 hours after 
which 4 to 5 drops of methyl red reagent was added to the solution, shaken and read at once. Positive reaction is indicated by a bright red colour while a yellow colour shows a negative test.

\section{Voges-Proskauer Test}

The principle of this test is the fact that bacteria ferment carbohydrates with the production of Acetyl methyl carbinol $\left(\mathrm{C}_{4} \mathrm{H}_{8} \mathrm{O}_{2}\right)$ or its reduction product 2, 3-Butylene glycol $\left(\mathrm{C}_{4} \mathrm{H}_{10} \mathrm{O}_{2}\right)$ (Carton, 1993). Buffered glucose broth was inoculated with the test organisms and incubated at $37^{\circ} \mathrm{C}$ for 48 hours. Three $3 \mathrm{ml}$ of alpha-naphthol and $1 \mathrm{ml}$ of $40 \%$ potassium hydroxide $(\mathrm{KOH})$ were added and the mixture properly shaken. A colour change to pink depicts a positive test while no colour change depicts a negative test.

\section{RESULTS AND DISCUSSION}

All fish samples examined in this study looked physically healthy based on their appearance but they were all infected with the "ever -ubiquitous" bacteria. The bacteria load of all skin, intestine and gills of all the fish sampled from the different locations showed that the fishes are contaminated. Table 1 shows the microbial load found in different parts of $C$. gariepinus from the ponds of the different locations. There was no significant difference $(\mathrm{p}<0.05)$ in the bacteria load in the skin, gills and intestines from Agip, Aluu and Woji. However, fish from Aluu had the highest bacteria count in the skin $\left(0.0094 \pm 0.0033 \times 10^{5} \mathrm{cfu} / \mathrm{g}\right)$. This was followed by fish from Woji $\left(0.0066 \pm 0.0102 \times 10^{5} \mathrm{cfu} / \mathrm{g}\right)$ and then Agip $\left(0.0046 \pm 0.0019 \times 10^{5} \mathrm{cfu} / \mathrm{g}\right)$. For gills, fish from Agip had the highest bacteria count $\left(0.0255 \pm 0.0128 \times 10^{5} \mathrm{cfu} / \mathrm{g}\right)$. This was followed by fish from Woji $(0.0109 \pm 0.0030)$ and then Aluu $(0.0073 \pm 0.0030)$. For intestine, fish from Aluu had the highest bacteria count $(0.0129 \pm 0.0040)$. This was followed by Woji $(0.0094 \pm 0.0030)$ and then Agip (0.0079 \pm 0.0026$)$.

Table 1. Bacteria count found in different parts of C. gariepinus

\begin{tabular}{|l|l|l|l|l|}
\hline Location & $\mathbf{N}$ & $\begin{array}{l}\text { Skin } \\
\left.\mathbf{1 0}^{\mathbf{5}} \mathbf{C F U} / \mathbf{G}\right)\end{array}$ & $\begin{array}{l}\text { Gills } \\
\left.\mathbf{( 1 0}^{\mathbf{5}} \mathbf{C F U} / \mathbf{G}\right)\end{array}$ & $\begin{array}{l}\text { Intestine } \\
\left.\mathbf{( 1 0}^{\mathbf{5}} \mathbf{C F U} / \mathbf{G}\right)\end{array}$ \\
\hline Agip & 12 & $0.0046 \pm 0.0019$ & $0.0255 \pm 0.0128$ & $0.0079 \pm 0.0026$ \\
\hline Aluu & 12 & $0.0094 \pm 0.0033$ & $0.0073 \pm 0.0030$ & $0.0129 \pm 0.0040$ \\
\hline Woji & 12 & $0.0066 \pm 0.0102$ & $0.0109 \pm 0.0030$ & $0.0094 \pm 0.0030$ \\
\hline
\end{tabular}

The gills had the highest bacteria count $\left(0.0255 \pm 0.0128 \times 10^{5} \mathrm{cfu} / \mathrm{g}\right)$ while the skin had the least bacteria count $\left(0.0046 \pm 0.0019 \times 10^{5} \mathrm{cfu} / \mathrm{g}\right)$ for fish from Agip. The intestine had the highest bacteria count $\left(0.0129 \pm 0.0040 \times 10^{5} \mathrm{cfu} / \mathrm{g}\right)$ the gills had the least had the least bacteria count $(0.0073 \pm 0.0030 \mathrm{x}$ $\left.10^{5} \mathrm{cfu} / \mathrm{g}\right)$ for fish from Aluu. The gills had the highest bacteria count $\left(0.0109 \pm 0.0030 \times 10^{5} \mathrm{cfu} / \mathrm{g}\right)$ while the skin had the least bacteria count $\left(0.0066 \pm 0.0102 \times 10^{5}\right)$ for fish tissues from Woji. These contamination was less in contrast with the work done on wild and cultured C. gariepinus in Ibadan by (Emikpe et al., 2011) and also with the work done on C. gariepinus in Abeokuta by (Oladosu et al., 2011). This is higher than the set standard for the acceptable level of microbiological safety of foods which is 1-100cfu/g (Ayinla et al., 1994).

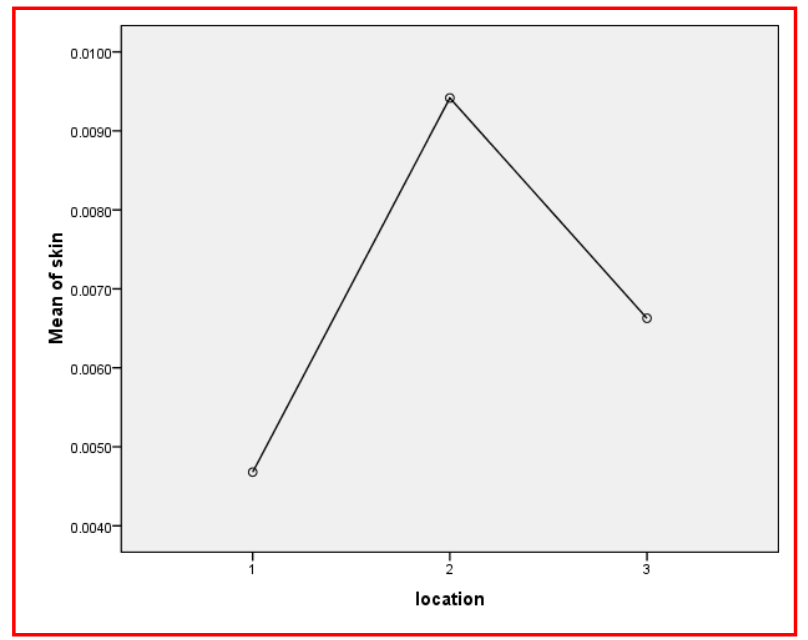

Key: Location 1 Agip; Location 2 Aluu; Location 3 Woji

Figure 1. Incidence of bacteria load on the skin of C. gariepinus from the different locations 
Most bacteria species were identified, present in Clarias gariepinus (Table 2), which include both pathogenic and normal flora. These bacteria species found in the tissues of C. gariepinus in this study were similar to the ones isolated in cultured C. gariepinus by Emikpe et al. (2011) and Oladosu et al. (2011). The occurrence of these bacteria species in different organs of fish (Figures1 to 3), could be an indication of presence of certain predisposing as handling of the fish, feeding of the fish, changing water as at when necessary and also cleaning and disinfecting the ponds. Some normal floral of humans such as Staphylococcus sp. Streptococcus sp were found predominant in the fish tissues from the different location. This could be based on the obtainable practices in the fish farm of the various locations such as handling could have introduced these bacteria species.

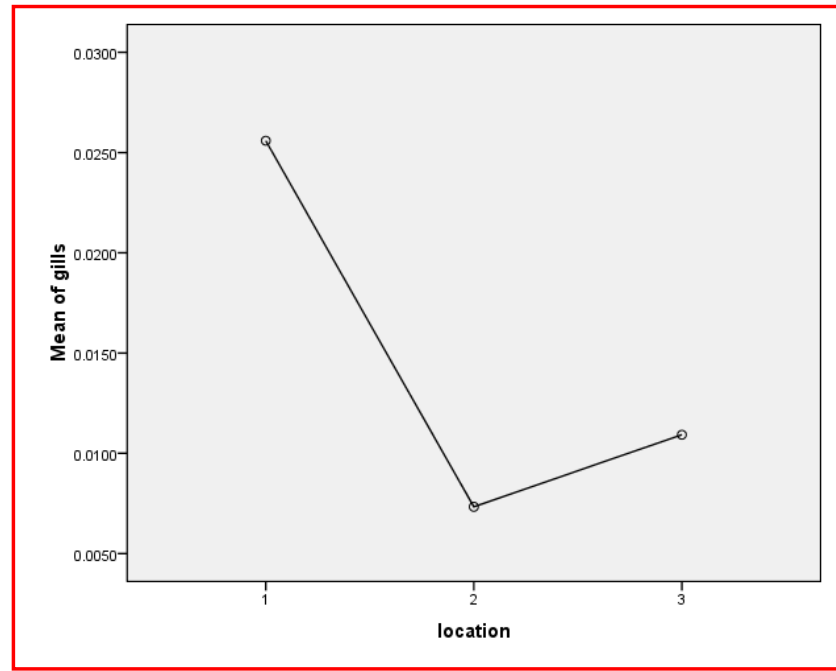

Location 1 - Agip ; Location 2- Aluu; Location 3- Woji

Figure 2. Incidence of bacteria load in the gills of $C$. gariepinus from the different locatio

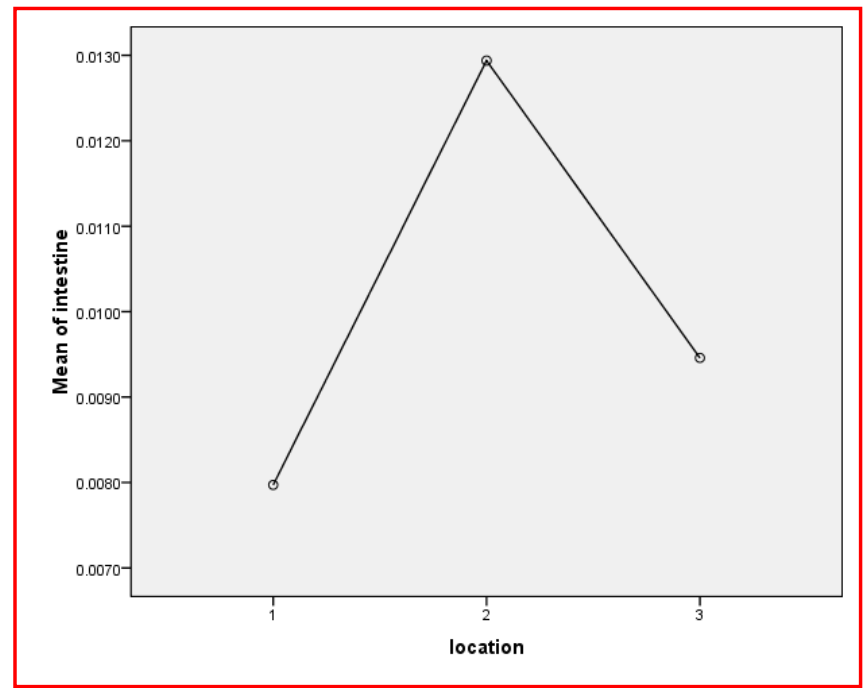

Location 1 - Agip ; Location 2- Aluu; Location 3- Woji

Figure 3. Incidence of bacteria load in intestines of $C$. gariepinus from the different location

Table 2. Diversity and incidenceloccurrence of Bacteria in C. gariepinus

\begin{tabular}{|l|l|l|l|}
\hline S/No & Bacterial Species & Frequency of Occurrence & \% Occurrence \\
\hline 1. & Pseudomonas sp & 2 & 7.14 \\
\hline 2. & Streptococcus sp & 9 & 32.1 \\
\hline 3 & Bacillus sp & 3 & 10.7 \\
\hline 4 & E.coli & 2 & 7.14 \\
\hline 5 & Staphylococcus sp. & 12 & 42.9 \\
\hline TOTAL & $\mathbf{2 8}$ & $\mathbf{1 0 0}$ \\
\hline
\end{tabular}




\section{Abu Onisokyetu Monica Godwin \& Uwadirioha Uchechi}

The isolates were characterized using various characteristics as tested by biochemical test, plate colonial morphology. The bacteria identified are shown in Table 3.The bacteria isolates identified in C. gariepinus include: Staphylococcus sp. Streptococcus sp, Pseudomonas sp, Bacillus sp and Escherichia coli. The coagulase Staphylococcus positive species are the species with the broadest pathogenic potential for causing infection of the skin, deeper tissues and organs, pneumonia, enteritis and pseudomembranous enterocolitis and food poisoning. In contrast to the coagulase Staphylococcus positive species members of the heterogenous group of coagulase negative Staphylococci (CNS) are regarded as less pathogenic bacteria (Efiuwewere and Ajiboye, 1996; Ogbulie et al., 2007). The presence of enteric organisms such as $E$. coli is particularly an indicator of fecal contamination in water bodies (indicator Organisms) (Willey et al., 2008). Contamination with E. coli in fish tissue in Aluu could be explained as a result of runoff. Some strains of E. coli are capable of causing food borne disease, ranging from mild enteritis to serious illness leading to death. There's a risk that pathogenic strains of $E$. coli may be present in pond water when animal manure such as bovine used in fertilizing ponds (WHO 1997).

Table 3. Characterization of Bacteria Isolates

\begin{tabular}{|c|c|c|c|c|c|c|c|c|c|c|c|c|c|c|c|c|c|c|}
\hline \multirow{2}{*}{\begin{tabular}{l|}
$\mathbf{S}$ \\
$/$ \\
$\mathbf{N}$ \\
\end{tabular}} & \multicolumn{7}{|c|}{ COLONIAL MORPHOLOGY } & \multicolumn{10}{|c|}{ BIOCHEMICAL TEST } & \multirow{2}{*}{$\begin{array}{l}\text { ISOLATED } \\
\text { ORGANIS } \\
\text { M }\end{array}$} \\
\hline & & $\begin{array}{l}\text { Pigmen } \\
\text { tation }\end{array}$ & $\begin{array}{l}\text { Surfa } \\
\text { ce }\end{array}$ & Edge & \begin{tabular}{|l} 
Eleva \\
tion
\end{tabular} & \begin{tabular}{|l|} 
Shap \\
e
\end{tabular} & $\begin{array}{l}\text { Arrang } \\
\text { ement }\end{array}$ & \begin{tabular}{|l} 
Gra \\
m \\
Rea \\
ctio \\
n \\
\end{tabular} & $\begin{array}{l}\mathbf{C} \\
\mathbf{A} \\
\mathbf{T}\end{array}$ & $\begin{array}{l}\mathbf{C} \\
\mathbf{O} \\
\mathbf{A}\end{array}$ & $\begin{array}{l}\mathbf{M} \\
\mathbf{O} \\
\mathbf{T}\end{array}$ & \begin{tabular}{|l|}
$\mathbf{O}$ \\
$\mathbf{X I}$
\end{tabular} & $\begin{array}{l}\mathbf{G} \\
\mathbf{L} \\
\mathbf{Y}\end{array}$ & $\begin{array}{l}\mathbf{L} \\
\mathrm{A} \\
\mathrm{C}\end{array}$ & $\begin{array}{l}\mathbf{M} \\
\mathbf{A} \\
\mathbf{L}\end{array}$ & $\begin{array}{l}\mathbf{M} \\
\mathbf{R}\end{array}$ & $\begin{array}{l}\mathbf{V} \\
\mathbf{P}\end{array}$ & \\
\hline 1 & $\begin{array}{l}\text { AGF } \\
\text { S }\end{array}$ & Yellow & $\begin{array}{l}\text { Gloss } \\
\mathrm{y}\end{array}$ & Entire & $\begin{array}{l}\text { Raise } \\
\text { d }\end{array}$ & $\begin{array}{l}\text { Roun } \\
\mathrm{d}\end{array}$ & \begin{tabular}{|l|} 
Cocci \\
in \\
clusters \\
\end{tabular} & + & + & + & - & - & + & + & + & + & - & $\begin{array}{l}\text { Staphylococc } \\
\text { us sp }\end{array}$ \\
\hline 2 & $\begin{array}{l}\text { AGF } \\
\text { IN }\end{array}$ & Creamy & $\begin{array}{l}\text { Wrin } \\
\text { kled }\end{array}$ & $\begin{array}{l}\text { Undu } \\
\text { lated }\end{array}$ & \begin{tabular}{|l|} 
Slight \\
ly \\
raised
\end{tabular} & \begin{tabular}{|l|} 
Irreg \\
ular
\end{tabular} & Rod & + & + & - & + & - & + & + & + & + & - & Bacillus sp \\
\hline 3 & $\begin{array}{l}\text { AGF } \\
\text { G } \\
\end{array}$ & Creamy & \begin{tabular}{|l|}
$\begin{array}{l}\text { Smoo } \\
\text { th }\end{array}$ \\
\end{tabular} & $\begin{array}{l}\text { Undu } \\
\text { lated }\end{array}$ & \begin{tabular}{|l|} 
Raise \\
$\mathrm{d}$
\end{tabular} & \begin{tabular}{|l|} 
Irreg \\
ular
\end{tabular} & Rods & - & + & - & + & - & + & + & + & + & - & E.coli \\
\hline 4 & $\begin{array}{l}\text { AGF } \\
\text { G }\end{array}$ & Yellow & $\begin{array}{l}\text { Gliste } \\
\text { ring }\end{array}$ & Entire & $\begin{array}{l}\text { Cove } \\
\mathrm{x}\end{array}$ & $\begin{array}{l}\text { Roun } \\
\mathrm{d}\end{array}$ & \begin{tabular}{|l|} 
Cocci \\
in \\
chains
\end{tabular} & + & - & - & - & - & + & + & + & + & - & $\begin{array}{l}\text { Streptococcu } \\
\text { s sp }\end{array}$ \\
\hline 5 & $\begin{array}{l}\text { AGF } \\
\text { G }\end{array}$ & Cream & $\begin{array}{l}\text { Gloss } \\
\mathrm{y}\end{array}$ & Entire & $\begin{array}{l}\text { Raise } \\
\text { d }\end{array}$ & $\begin{array}{l}\text { Roun } \\
\mathrm{d}\end{array}$ & \begin{tabular}{|l|} 
Cocci \\
In \\
Clusters
\end{tabular} & + & + & + & - & - & + & + & + & + & - & $\begin{array}{l}\text { Staphylococc } \\
\text { us sp }\end{array}$ \\
\hline 6 & $\begin{array}{l}\text { AGF } \\
\text { IN }\end{array}$ & Yellow & $\begin{array}{l}\text { Gliste } \\
\text { ring }\end{array}$ & $\begin{array}{l}\text { Rhizo } \\
\text { id }\end{array}$ & Flat & \begin{tabular}{|l|} 
Irreg \\
ular
\end{tabular} & $\begin{array}{l}\text { Cocci } \\
\text { in } \\
\text { chains }\end{array}$ & + & - & - & - & - & + & + & + & + & - & $\begin{array}{l}\text { Streptococcu } \\
\text { s sp }\end{array}$ \\
\hline 7 & $\begin{array}{l}\text { AGF } \\
\text { IN }\end{array}$ & Cream & $\begin{array}{l}\text { Gliste } \\
\text { ring }\end{array}$ & $\begin{array}{l}\text { Serrat } \\
\text { ed }\end{array}$ & $\begin{array}{l}\text { Conv } \\
\text { ex }\end{array}$ & \begin{tabular}{|l|} 
Irreg \\
ular
\end{tabular} & $\begin{array}{l}\text { Cocci } \\
\text { in } \\
\text { chains } \\
\end{array}$ & + & - & - & - & - & - & + & + & - & - & $\begin{array}{l}\text { Streptococcu } \\
\text { s sp }\end{array}$ \\
\hline 8 & \begin{tabular}{|l} 
AGF \\
IN
\end{tabular} & Pink & $\begin{array}{l}\text { Gliste } \\
\text { ring }\end{array}$ & Entire & \begin{tabular}{|l} 
Slight \\
ly \\
raised
\end{tabular} & \begin{tabular}{|l|} 
Irreg \\
ular
\end{tabular} & $\begin{array}{l}\text { Cocci } \\
\text { in } \\
\text { chains }\end{array}$ & + & + & + & - & - & - & + & + & - & - & \begin{tabular}{|l|} 
Streptococcu \\
s sp
\end{tabular} \\
\hline 9 & $\begin{array}{l}\text { AGF } \\
\text { S }\end{array}$ & Cream & Dull & Entire & Flat & \begin{tabular}{|l|} 
Irreg \\
ular
\end{tabular} & Rod & + & + & - & + & - & + & + & + & - & - & Bacillus sp \\
\hline $\begin{array}{l}1 \\
0\end{array}$ & $\begin{array}{l}\text { AGF } \\
\text { G }\end{array}$ & Cream & $\begin{array}{l}\text { Gliste } \\
\text { ring }\end{array}$ & $\begin{array}{l}\text { Rhizo } \\
\text { id }\end{array}$ & Flat & \begin{tabular}{|l|} 
Irreg \\
ular
\end{tabular} & \begin{tabular}{|l|} 
Cocci \\
in \\
chains \\
\end{tabular} & + & + & - & + & + & - & + & + & + & - & $\begin{array}{l}\text { Streptococcu } \\
\text { s sp }\end{array}$ \\
\hline $\begin{array}{l}1 \\
1\end{array}$ & $\begin{array}{l}\text { AGF } \\
\text { G }\end{array}$ & \begin{tabular}{|l|} 
Yellow \\
\end{tabular} & Dull & $\begin{array}{l}\text { Serrat } \\
\text { ed }\end{array}$ & Flat & \begin{tabular}{|l|} 
Roun \\
d
\end{tabular} & \begin{tabular}{|l|} 
Cocci \\
in \\
clusters
\end{tabular} & + & + & + & - & - & + & + & + & + & - & $\begin{array}{l}\text { Streptococcu } \\
\text { s sp }\end{array}$ \\
\hline $\begin{array}{l}1 \\
2\end{array}$ & $\begin{array}{l}\text { AGF } \\
\text { IN }\end{array}$ & Cream & Dull & Entire & $\begin{array}{l}\text { Raise } \\
\text { d }\end{array}$ & $\begin{array}{l}\text { Roun } \\
\text { d }\end{array}$ & \begin{tabular}{|l|} 
Cocci \\
in \\
clusters \\
\end{tabular} & + & + & + & - & - & + & + & + & - & - & $\begin{array}{l}\text { Streptococcu } \\
\text { s sp }\end{array}$ \\
\hline $\begin{array}{l}1 \\
3\end{array}$ & $\begin{array}{l}\text { AGF } \\
\mathrm{S}\end{array}$ & Cream & $\begin{array}{l}\text { Gliste } \\
\text { ring }\end{array}$ & Entire & $\begin{array}{l}\text { Conv } \\
\text { ex }\end{array}$ & $\begin{array}{l}\text { Roun } \\
\mathrm{d}\end{array}$ & \begin{tabular}{|l|} 
Cocci \\
in \\
clusters
\end{tabular} & + & + & - & - & - & - & + & + & + & - & $\begin{array}{l}\text { Streptococcu } \\
\text { s sp }\end{array}$ \\
\hline $\begin{array}{l}1 \\
4\end{array}$ & $\begin{array}{l}\text { ALF } \\
\text { S }\end{array}$ & Cream & $\begin{array}{l}\text { Gloss } \\
\mathrm{y}\end{array}$ & $\begin{array}{l}\text { Serrat } \\
\text { ed }\end{array}$ & Flat & $\begin{array}{l}\text { Roun } \\
\text { d }\end{array}$ & \begin{tabular}{|l|} 
Cocci \\
in \\
clusters \\
\end{tabular} & + & + & - & - & - & - & + & + & + & - & $\begin{array}{l}\text { Streptococcu } \\
\text { s sp }\end{array}$ \\
\hline 5 & \begin{tabular}{|l} 
ALFI \\
$\mathrm{N}$
\end{tabular} & Cream & $\begin{array}{l}\text { Wrin } \\
\text { kled }\end{array}$ & Entire & \begin{tabular}{|l|} 
Slight \\
ly
\end{tabular} & \begin{tabular}{|l|}
$\begin{array}{l}\text { Irreg } \\
\text { ular }\end{array}$ \\
\end{tabular} & Rod & + & + & - & + & & + & + & + & + & - & Bacillus sp \\
\hline
\end{tabular}


Comparative Study on Bacterial Load in Intestine, Gills and Skin of Cultured African Catfish (Clarias Gariepinus) from Different Locations in Rivers State, Nigeria

\begin{tabular}{|c|c|c|c|c|c|c|c|c|c|c|c|c|c|c|c|c|c|c|}
\hline & & & & & raised & & & & & & & & & & & & & \\
\hline $\begin{array}{l}1 \\
6\end{array}$ & $\begin{array}{l}\text { ALF } \\
\text { G }\end{array}$ & White & $\begin{array}{l}\text { Gliste } \\
\text { ring }\end{array}$ & $\begin{array}{l}\text { Entrir } \\
\mathrm{e}\end{array}$ & $\begin{array}{l}\text { Conv } \\
\text { ex }\end{array}$ & $\begin{array}{l}\text { Roun } \\
\text { d }\end{array}$ & $\begin{array}{l}\text { Cocci } \\
\text { in } \\
\text { chains }\end{array}$ & + & - & - & - & - & - & + & + & - & - & $\begin{array}{l}\text { Streptococcu } \\
\text { s sp }\end{array}$ \\
\hline $\begin{array}{l}1 \\
7\end{array}$ & $\begin{array}{l}\text { ALF } \\
\text { G }\end{array}$ & Yellow & $\begin{array}{l}\text { Gloss } \\
\mathrm{y}\end{array}$ & $\begin{array}{l}\text { Serrat } \\
\text { ed }\end{array}$ & $\begin{array}{l}\text { Raise } \\
\text { d }\end{array}$ & $\begin{array}{l}\text { Roun } \\
\text { d }\end{array}$ & $\begin{array}{l}\text { Cocci } \\
\text { in } \\
\text { clusters }\end{array}$ & + & + & + & - & - & - & + & + & + & - & $\begin{array}{l}\text { Streptococcu } \\
\text { s sp }\end{array}$ \\
\hline $\begin{array}{l}1 \\
8\end{array}$ & \begin{tabular}{|l|} 
ALFI \\
$\mathrm{N}$
\end{tabular} & Cream & Dull & Entire & Flat & $\begin{array}{l}\text { Irreg } \\
\text { ular }\end{array}$ & Rods & - & + & - & + & - & + & + & & + & - & E.coli \\
\hline $\begin{array}{l}1 \\
9 \\
\end{array}$ & WFS & Pink & Dull & Entire & $\begin{array}{l}\text { Raise } \\
\mathrm{d}\end{array}$ & $\begin{array}{l}\text { Irreg } \\
\text { ular }\end{array}$ & Rods & - & + & - & + & + & - & + & + & - & - & $\begin{array}{l}\text { Pseudomona } \\
\text { s sp }\end{array}$ \\
\hline $\begin{array}{l}2 \\
0\end{array}$ & WFS & Write & $\begin{array}{l}\text { Gliste } \\
\text { ring }\end{array}$ & Entire & $\begin{array}{l}\text { Conv } \\
\text { ex }\end{array}$ & $\begin{array}{l}\text { Roun } \\
\text { d }\end{array}$ & $\begin{array}{l}\text { Cocci } \\
\text { in } \\
\text { chains }\end{array}$ & + & + & - & - & + & - & + & + & + & - & $\begin{array}{l}\text { Streptococcu } \\
\text { s sp }\end{array}$ \\
\hline $\begin{array}{l}2 \\
1\end{array}$ & WFS & Cream & $\begin{array}{l}\text { Gliste } \\
\text { ring }\end{array}$ & Entire & $\begin{array}{l}\text { Conv } \\
\text { ex }\end{array}$ & $\begin{array}{l}\text { Irreg } \\
\text { ular }\end{array}$ & Rods & - & + & - & + & $=$ & + & + & + & - & - & $\begin{array}{l}\text { Pseudomona } \\
\text { s sp }\end{array}$ \\
\hline $\begin{array}{l}2 \\
2\end{array}$ & WFG & Cream & Dull & Entire & Flat & $\begin{array}{l}\text { Roun } \\
\text { d }\end{array}$ & $\begin{array}{l}\text { Cocci } \\
\text { in } \\
\text { clusters }\end{array}$ & + & + & - & - & - & - & + & + & + & - & $\begin{array}{l}\text { Staphylococc } \\
\text { us sp }\end{array}$ \\
\hline $\begin{array}{l}2 \\
3\end{array}$ & WFG & White & $\begin{array}{l}\text { Gliste } \\
\text { ring }\end{array}$ & $\begin{array}{l}\text { Serrat } \\
\text { ed }\end{array}$ & $\begin{array}{l}\text { Conv } \\
\text { ex }\end{array}$ & \begin{tabular}{|l} 
Irreg \\
ular
\end{tabular} & $\begin{array}{l}\text { Cocci } \\
\text { in } \\
\text { chains }\end{array}$ & + & + & - & - & + & - & + & + & + & + & \begin{tabular}{|l|} 
Streptococcu \\
s sp
\end{tabular} \\
\hline $\begin{array}{l}2 \\
4\end{array}$ & WFG & Cream & $\begin{array}{l}\text { Gloss } \\
\mathrm{y}\end{array}$ & $\begin{array}{l}\text { Serrat } \\
\text { ed }\end{array}$ & $\begin{array}{l}\text { Raise } \\
\text { d }\end{array}$ & $\begin{array}{l}\text { Roun } \\
\text { d }\end{array}$ & $\begin{array}{l}\text { Cocci } \\
\text { in } \\
\text { clusters }\end{array}$ & + & + & + & - & - & + & + & + & - & - & $\begin{array}{l}\text { Staphylococc } \\
\text { us sp }\end{array}$ \\
\hline $\begin{array}{l}2 \\
5\end{array}$ & WFS & Cream & $\begin{array}{l}\text { Gloss } \\
\mathrm{y}\end{array}$ & \begin{tabular}{|l|} 
Roun \\
d
\end{tabular} & Flat & $\begin{array}{l}\text { Roun } \\
\text { d }\end{array}$ & \begin{tabular}{|l|} 
Cocci \\
in \\
clusters \\
\end{tabular} & + & + & + & + & - & - & + & + & + & - & $\begin{array}{l}\text { Staphylococc } \\
\text { us sp }\end{array}$ \\
\hline $\begin{array}{l}2 \\
6\end{array}$ & WFS & Yellow & $\begin{array}{l}\text { Gliste } \\
\text { ring }\end{array}$ & $\begin{array}{l}\text { Roun } \\
\text { d }\end{array}$ & $\begin{array}{l}\text { Conv } \\
\text { ex }\end{array}$ & $\begin{array}{l}\text { Roun } \\
\text { d }\end{array}$ & $\begin{array}{l}\text { Cocci } \\
\text { in } \\
\text { chains }\end{array}$ & + & + & - & - & - & + & + & + & + & - & $\begin{array}{l}\text { Streptococcu } \\
\text { s sp }\end{array}$ \\
\hline $\begin{array}{l}2 \\
7\end{array}$ & $\begin{array}{l}\text { WFI } \\
\mathrm{N}\end{array}$ & Cream & Dull & Entire & $\begin{array}{l}\text { Raise } \\
\text { d }\end{array}$ & $\begin{array}{l}\text { Irreg } \\
\text { ular }\end{array}$ & $\begin{array}{l}\text { Cocci } \\
\text { in } \\
\text { cluster }\end{array}$ & + & + & + & - & - & + & + & + & + & - & $\begin{array}{l}\text { Staphylococc } \\
\text { us sp }\end{array}$ \\
\hline $\begin{array}{l}2 \\
8\end{array}$ & $\begin{array}{l}\text { WFI } \\
\mathrm{N}\end{array}$ & Yellow & $\begin{array}{l}\text { Gloss } \\
\mathrm{y}\end{array}$ & Entire & $\begin{array}{l}\text { Raise } \\
\text { d }\end{array}$ & $\begin{array}{l}\text { Roun } \\
\text { d }\end{array}$ & $\begin{array}{l}\text { Cocci } \\
\text { in } \\
\text { clusters }\end{array}$ & + & + & + & - & - & + & + & + & + & - & $\begin{array}{l}\text { Staphylococc } \\
\text { us sp }\end{array}$ \\
\hline
\end{tabular}

Key : AL-Aluu; AG- Agip; W-Woji; F-Fish; Cat-Catalyst; Coa-Coagulase; Mot- Motility; OxiOxidase; Glu-Glucose; Lac-Lactose; Mal-Maltise; M.R-Methylred; V.P-Voges-Proskauer

The high bacteria load in these fishes as a source of proteins to humans, poses a hazard to the consumers health as some of the isolated species as Bacillus sp. Staphylococcus, are noted for very severe disease of man while some other species such as Pseudomonas, E. Coli may cause diseases in certain fish species such as Tilapia or be a source of zoonosis to humans (Edun et al., 2007).

\section{CONCLUSION AND RECOMMENDATION}

This study have shown that fish samples from the different locations were all contaminated with most bacteria species which include normal flora as well as the pathogenic forms of bacteria. The isolation of these organisms from the tissues of $C$. gariepinus is worrisome because of their potential in causing ill-health to human. It is okay to assume that these organisms might be introduced into the ponds by human healthy carriers through handling. Based on this study which identified the presence of bacteria organisms it is therefore recommended that better aquaculture practices be employed so as to reduce the chances of these bacterial contamination. The sanitary conditions under which fishes are reared in ponds should be improved by following standard practices such as use of good quality water free of contamination, treatment of organic manure before introduction into ponds, the use of feed free of contaminants regular draining of pond after specific period of time etc. the microbial load of fish can also be improved through regular disinfection of working equipment, brief immersion of the fishes in disinfecting solution such as brine water to reduce the microbial load on the fish before storage or before it is sold to the public for consumption. Before consumption, cooking of fish properly should also be done, as heat kills most of the microorganism if not all. 


\section{REFERENCE}

[1] Adebayo-Tayo B.C; Odu, NN: Michael M; Okonko (2012a). Multi-Drug Resistant (MDR) Organisms Isolated from Seafoods in Uyo, South-Southern Nigeria. Nature and Science; 10(3): 61-70.

[2] Adebayo-Tayo, B.C., Odu,N.N., Anyamele,L.M.,Igwiloh, N.J and Okonko, I.O.(2012b). Microbial quality of frozen fish sold in Uyo metropolis. African Journal of Biotechnology, 8(13):3068-3071.

[3] Adeleye, I.A., Daniels, F.V., and Eyinnia, V.A. (2010). Characterization and pathogenicity of vibrio spp. contaminating sea foods in Lagos, Nigeria. Internet Journal of Food Safety, 12:1-9.

[4] Ayinla, O.A., G.A. Oladosu, M.O.Ajiboye and E.J.Ansa, (1994). Pollution and health harzards of intergrated livestock cum fish farming system in Nigeria. Proceeding of the CIFIA aeminar of African inland fisheries, Aquaculture and the Environment, December 5-7, 1994, Harare, Zimbabwe, PP: 20.

[5] Carlton, J. T. (1993) An international Perspective on Species, Introductions; the ICES Protocol: 31-34.

[6] Cheeseborough, M. (1985). Medical Labouratory MAnnual for Tropical Countries, Butterworth. Heineman Ltd., Jordasn Hill Oxford London, P. 61-274.

[7] Edun, O.M. Akunsotimi, O., Opara J.Y., Owhonda, K. N., Onunkwo, D. N and Anyanwu, P. E. (2007). Public Health and Economic Implication of the Microbial Flora of Cultivable Freshwater Fishes. Journal of Fisheries International 2(4): 274-276.

[8] Edun, O.M., Akinrotimi, O.A., Makinde, O.O. (2015). Seasonal changes of microbial load in some sea foods from Buguma and Ekerekana creeks, Niger Delta, Nigeria. Journal of Environmental Science and Toxicology, 1(1), 001-007.

[9] Efiuwewere, B.J.O. and M.O. Ajiboye, (1996). Control of microbiological quality and shelf-life of catfish (Clairias gariepinus) by chemical preservation and smoking. Journal of Applied Bacteriology, 80:465-470.

[10] Emikpe B. O, Adebisi T. and Adedeji O. B. 2011. Bacteria Load on the Skin and stomach of Clarias Gariepinus and Oreochsomis Niloticus from Ibadan, South West Nigeria: Public Health Implications. J. Microbiol. Biotech,. Res., 1 (1): 52-59.

[11] FDF (2007): Federal Department of Fisheries. Fisheries Statestics of Nigeria, Fourth Edition: $1995-2007$ pp 49.

[12] FDF (2010): Federal Department of Fisheries. Fisheries Statestics of Nigeria, Fifth Edition: 2007-2010 pp 109.

[13] FDF (2014): Federal Department of Fisheries. Fisheries Statestics of Nigeria, Seventh Edition: 2012-2014 pp 231.

[14] FAO (1994): Food and Agriculture Organization of the United Nations: Review of the State of the World Fishery Resources, Marine Fisheries: FAO Fishery Circular No. 920, Rome.

[15] Ogbulie, T.E., Ogbulie, J.N., and Njoku, H.O.(2007). Comparative study on the microbiology and shelf life stability of palm wine from Elaeis guineensis and Raphia hookeri obtained from Okigwe, Nigeria.African Journal of Biotechnology, 6(7):914-922.

[16] Oladosu, G. A., O. A. Ayinla and M.O Ajiboye, (2011). Isolation and Pathogen city of Bacillus sp. Associated with a septicaemic Condition in some Tropical Freshwater Fish Species. Journal of Applied Ichthyology, 10:69-72.

[17] Wafaa M..K., Bakr, Walaa A. Hazzah Amani F. Abaza (2011). Detection of Salmonella and Vibrio Species in some Seafood in Alexandra. Journal of American Science, 7(9): 663-668.

[18] WHO (2007): Food Safety Issues Associated with Products from Aquaculture. Report of a Joint FAO/NACA/WHO Study Group. WHO Technical Repent Series: 883 Genera.

[19] Willey, J.M.; Sherwood, L.M; Woolverton, C,(2008) Prescott, Harley and Klein's Microbiology. McGraw Hill Higher Education, New York. 


\section{AUTHOR'S BIOGRAPHY}

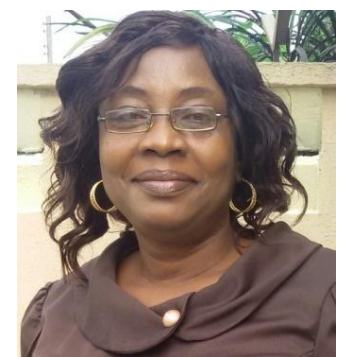

Dr. (Mrs.) O. M. G. Abu, is a Senior Lecturer in the Department of Fisheries, Faculty of Agriculture, University of Port Harcourt. She is a renowned expert, specializing in Aquaculture, Catfish Fingerling Production, Establishment of Fish Farms and Fish Nutrition and Processing. She is especially noted for her efforts in giving quality supervision to students in their research projects for good project work, improving learning and bringing the project to a good conclusion adding to knowledge. Dr. Abu has carried out several researches and has several publications in international and local journals covering diverse areas in fisheries. Dr Abu's current research and interests revolve around the Development of best aquaculture practices for healthy fish production and food safety. Her past roles include being the Former Director of Fisheries, Rivers State Agricultural Development Programme, Rivers State Nigeria, Personal Assistant to Honorable Commissioner for Agriculture, Rivers State Nigeria. Rivers State Facilitator for Fisheries in National Special Programme for Food Security, a World Bank Sponsored Project. Fisheries Consultant, International Institute for Tropical Agriculture (IITA) Onne, Managing Director SAMMANI CONSULTS, a capacity building outfit on agriculture and has trained many members of agriculture cooperatives. She has consulted for many fish farms including the famous CANABU FARMS in Rivers State. Dr. Abu is the founder of Divine Love Project, an organization that supports less privileged and motherless babies. 